\title{
Caries prevalence in skeletal series - Is it possible to compare?
}

\author{
Veronica Wesolowski
}

\author{
Departamento de Endemias Samuel Pessoa, Escola Nacional de Saúde Publica Sérgio Arouca-Fiocruz, \\ Rua Leopoldo Bulhões 1480, 21041-210 Rio de Janeiro, RJ, Brasil
}

Because of the relationship with subsistence, dental caries is a central issue in paleopathological research. Usually, comparisons between caries prevalence exhibited in different skeletal series are made. Dietary variation is the most common explanation for cavities prevalence. The aim of this paper is to verify if it is possible to compare caries prevalence reported on papers for archaeological skeletal series. Another goal is to determine if other factors besides diet are implicated in dental cavity prevalence explanation. Twenty six papers about dental health with caries prevalences published from 1999 to 2004 were analyzed for completeness. This assessment includes carious lesion diagnosis and characteristics, age, sex and size characteristics of samples, and prevalence calculation method. The majority of the analyzed papers do not provide adequate information in the topics listed above. Only very few implicated factors other than diet as a contributor to caries lesions development.

Key words: methods - dental pathology - subsistence - diet - funerary samples - prehistory

Enamel mineralization makes teeth very resistant structures. They can be preserved even in poor preservation conditions. Since teeth are directly involving in the alimentary process and in many other cultural processes, especially when teeth are used as tools, they provide a large spectrum of research possibilities concerning subsistence, health, and life style in ancient human groups.

Several pionereeing investigators of Native American groups demonstrated that the caries prevalence increased following an increase in the amount of sugar in the diet (Waugh 1930, 1931, Waugh \& Waugh 1940). The recognition that the diet can play a role in the development of cavities pointed to the possibility that the diet of ancient human groups could be inferred through the patterns observed to the caries prevalence.

Although the study of subsistence through dental characteristics had always been present in the bio-archeological research, the importance of this line of investigation increased during the final of the 7th decade of the XX century.

The "New Paleopathology" brought a new perspective to the field including an epidemiological approach to the study of the health-disease processes in the past. Since the beginning of 1980s shifts in the subsistence patterns and life-styles have being the focus of many researches (Buikstra \& Cook 1992).

During the end of the 1970s and the beginning of the 1980s the evidence connecting diet to dental cavities prevalence increased. As a result, the idea that caries prevalence changes when diet changes became a frequent explanatory model. This model was supported by three

\footnotetext{
Financial support: Capes

${ }^{+}$Correspondent author: wesowski@woc.com.br

Received 20 July 2006

Accepted 16 October 2006
}

main research lines: surveys in the caries prevalence among many native Americans, Africans, Asians, and Aborigines living under several different subsistence strategies in traditional economies (hunter-gathers, incipient horticulturalists, and agriculturalists); paleopathological study of skeletal series recovered from well-know archeological contexts (including subsistence patterns), and contemporaneous populations living under no traditional subsistence systems (commercial and industrial agriculture, industrial societies) (Turner 1979, Cohen \& Armelagos 1984).

Tese lines of research shoud that dental caries prevalence is more pronouced in groups with large amounts of carbohydrates in the diet. So, hunter-gatherers have, in general, the lowest prevalence values and groups with a industrial economy have the highest caries prevalence values. Between the both extremes there are several others subsistence systems with variable consumption of rich carbohydrate food and variable caries prevalence values (Turner 1979, Cohen \& Armelagos 1984).

Since this early researchs, specific ranges of caries prevalence values are being associated with specific subsistence strategies and such associations are in the center of many interpretations about diet performed during paleopathological investigations in archeological skeletal samples. So the observed cavities prevalence is usually associated with the group's putative subsistence pattern and compared with caries prevalence ranges and/or values previously reported for other series presenting this same subsistence pattern.

Based upon the relationship between caries and diet, the prevalence of caries became a marker to access shifts in the subsistence pattern and, even without other material evidence, the cavities prevalence are frequently used to infer the group diet.

The goals of this paper are: (1) to do a systematic review of papers published in the last five years that foccus on dental caries as a main subject; (2) to evaluate the quality of the methodological information given in such papers; (3) to discuss the validity of comparisons between 
results obtained in different research, and; (4) to establish if any other factor than diet was implicated in the explanation of the caries causation in ancient human groups.

\section{MATERIAL AND METHODS}

This bibliographic review included papers that had, as study focus, dental caries in archeological skeletal samples, either prehistoric or historic, and that had being published in a five years before this review (between January 1999 and January 2004).

The following bibliographic databases were used to search papers related with the subject of this revision: Medline, Scielo, Biological Abstracts, CAB, ASFA, and human nutrition. In order to complete the investigation, I performed a direct search in the JSTOR database (Journal Storage - www.jstor.org ), as well as in my personal library and in the Biological Anthropology Laboratory's library (IB/USP). The cited references in the recovered papers were examined to find other papers of interest.

The language of the papers (Portuguese, French, English, Spanish, and Italian) and the mention of caries prevalence values in the papers were defined as inclusion criteria.

To evaluate the quality of the methodological information provided, five criteria were analyzed (Table I). Each criterion could be scored as positive $[+]$, negative $[-]$ or partial $[p]$. Considering each criterion, complete methodological information were scored as positive, no given methodological information were scored as negative and incomplete or unclear methodological information were scored as partial. When a criterion was scored as partial, the methodological information given in the paper was registered. "Positive $[+]$ " was the score considered desirable for all the analytical criteria. The frequency of papers showing positive, negative, and partial answer was calculated for each criterion.

A score system was created to classify the analyzed papers regarding their methodological information quality. Positive scores received 1 point, partial scores received 0.5 points and negative scores received 0 points. The maximum possible score for each paper was 5 points and the minimum 0 points.
The papers were classified according to the methodological information provided. Five qualitative classes were used: (i) 5 to 4,5 points- complete; (ii) 3 to 4 points sufficient; (iii) 2.5 -incomplete; (iv) 2 to 0.5 - very incomplete; (v) 0 - any methodological information was given.

After that classification, the frequency of papers in each of these categories was calculated.

In order to evaluate the use of diet as an explanatory mechanism to the presence of cavities and caries prevalence, the following information was searched for and extracted from the papers: (1) Did the author (s) explained the calculated caries prevalence in the studied groups using a relationship between caries and diet? (2) Did the author (s) considered any other factor than diet as a possible factor playing a role in the cavities development and/or used this factor to explain the observed prevalence even as a secondary possibility?

\section{RESULTS}

Twenty nine papers were recovered. From those, four were excluded from the analysis due to the absence of prevalence values (Antunes-Ferreira et al. 2000, Carnim et al. 2000, Domett et al. 2000, Santos \& Matos 2000).

Sciulli and Oberly (2002) presented two different data sets: one adressing the whole set of possible skeletal samples and other adressing only few selected skeletal samples. Since the methodology used to analyze each one of these data sets was different, the paper was analyzed as two different works and appears twice in the Table II.

The results found in the evaluation of the methodological quality for each criterion are presented in the Table II, as well the results found for the factor used to explain the caries prevalence.

Only one paper received the maximum score considering all defined criteria, being classified as complete. Fifty percent of the analyzed papers were scored in the 2.5 interval, being classified as incomplete. One paper made a 0 score and received the "no given information" classification. The identification of the analyzed paper and the respective score is in Table II. The scores obtained for each paper was in Table III and the percentage of papers in each quality interval is in Fig. 1.

TABLE I

Definition of criteria used in the methodological evaluation

\begin{tabular}{ll}
\hline Criteria & Characteristics \\
\hline $\begin{array}{l}\text { Description of the caries prevalence } \\
\text { calculation method (CPCM) }\end{array}$ & Accurate description of the method used to calculate the prevalence \\
$\begin{array}{l}\text { Description of the caries diagnostic } \\
\text { methods (CDM) }\end{array}$ & $\begin{array}{l}\text { Accurate description of the method used to diagnose cavities (visual inspection, } \\
\text { with or without use of dental probe, nature of illumination used, etc.) }\end{array}$ \\
$\begin{array}{l}\text { Description of the caries lesions } \\
\text { characteristics (CLC) }\end{array}$ & $\begin{array}{l}\text { Accurate description of the lesions morphology, anatomic location site, affected } \\
\text { teeth and definition of characteristics to considerate a lesion as cavitie }\end{array}$ \\
Samples characteristics (SC) & $\begin{array}{l}\text { Sexual and age composition for effectively analyzed samples } \\
\text { Specification of sample size (SZ) }\end{array}$ \\
& $\begin{array}{l}\text { Specification of size for the sample and/or sub-sample effectively used in caries } \\
\text { observation }\end{array}$
\end{tabular}




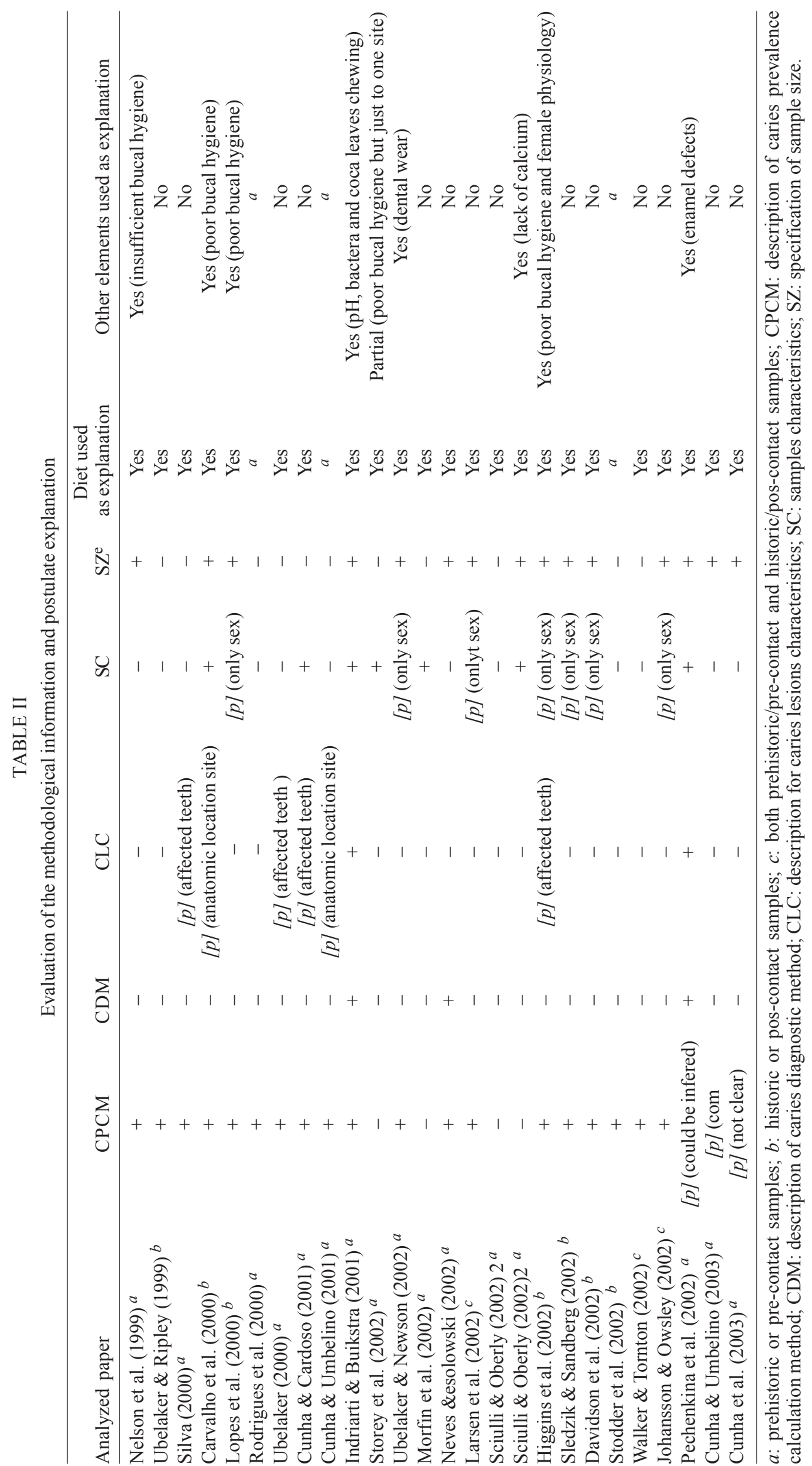


Among the five criteria defined as indicators of quality of methodological information, only the CPCM (description for caries prevalence calculation method) had a good performance and $73.08 \%$ of the papers showed clear and complete information about the method used to calculate the cavities prevalence. The other $11.54 \%$ showed partial (incomplete) information.

The worst result among all criteria was found in the description for caries diagnostic methods (CDM). In this criterion, $88.46 \%$ of analyzed papers received a negative evaluation. Although not showing a negative evaluation as the $\mathrm{CDM}$, the $\mathrm{SZ}$ criterion (specification of sample size) had a poor performance and only $57.69 \%$ of the papers have given this information (Table II, Fig. 2).

All but three papers used diet as the main factor explaining the caries prevalence found ( 23 papers). The three remaining papers did not consider any explanation for the observed cavities prevalence, because this was not one of their goals.

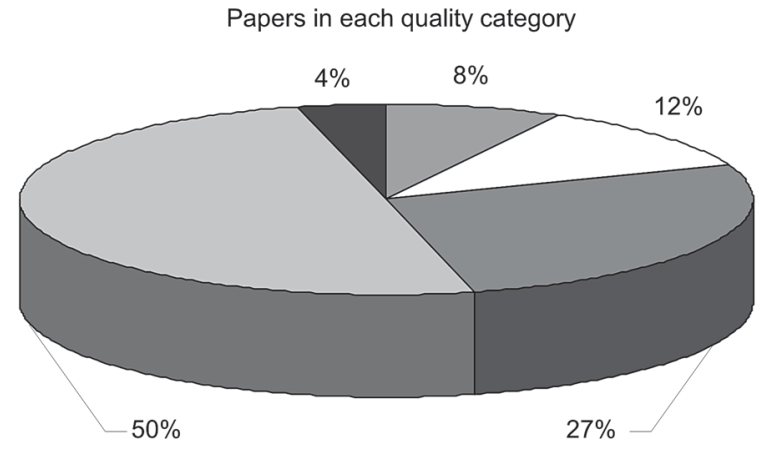

$\square$ Complete $\square$ Sufficient $\square$ Incomplete $\square$ Very incomplete $\square$ No information

Fig. 1: graphic showing the frequencies of papers in each qualitative category.



Fig. 2: frequency of papers concerning the received evaluation type (positive, negative or partial) for criterion. CPCM: caries prevalence calculation method; CDM: caries diagnostic method; CLC: caries lesions characteristics; SC: samples characteristics; SZ: samples size.
TABLE III

Scores and qualitative classification

\begin{tabular}{lcl}
\hline Analyzed paper & Score & $\begin{array}{l}\text { Qualitative } \\
\text { classification }\end{array}$ \\
\hline Nelson et al. (1999) & 2 & Very incomplete \\
Ubelaker \& Ripley (1999) & 1 & Very incomplete \\
Silva (2000) & 1,5 & Very incomplete \\
Carvalho et al. (2000) & 3,5 & Sufficient \\
Lopes et al. (2000) & 2,5 & Incomplete \\
Rodrigues et al. (2000) & 1 & Very incomplete \\
Ubelaker (2000) & 1,5 & Very incomplete \\
Cunha \& Cardoso (2001) & 2,5 & Incomplete \\
Cunha \& Umbelino (2001) & 1,5 & Very incomplete \\
Indriarti \& Buikstra (2001) & 5 & Complete \\
Storey et al. (2002) & 1 & Very incomplete \\
Ubelaker \& Newson (2002) & 2,5 & Inconplete \\
Morfin et al. (2002) & 1 & Very incomplete \\
Neves \& Wesolowski (2002) & 3 & Sufficient \\
Larsen et al. (2002) & 2,5 & Inconplete \\
Sciulli \& Oberly (2002) 3 & 0 & No information \\
Sciulli \& Oberly (2002) 3 & 2 & Very incomplete \\
Higgins et al. (2002) & 3 & Sufficient \\
Sledzik \& Sandberg (2002) & 2,5 & Inconplete \\
Davidson et al. (2002) & 2,5 & Inconplete \\
Stodder et al. (2002) & 1 & Very incomplete \\
Walker \& Tornton (2002) & 1 & Very incomplete \\
Johansson \& Owsley (2002) & 2,5 & Inconplete \\
Pechenkina et al. (2002) & 4,5 & Complete \\
Cunha \& Umbelino (2003) & 1,5 & Very incomplete \\
Cunha et al. (2003) & 1,5 & Very incomplete \\
\hline & &
\end{tabular}

Only nine papers, from the 23 which used diet as the main explanatory factor for the observed caries prevalence, implicated any other factor as potential element involved in the carious lesions development.

\section{DISCUSSION}

Valid comparison can only be performed if the factors involved in the comparison are equivalent. This implies that, to be possible to compare caries prevalence, this prevalence needs to be calculated from equivalent samples and using equivalent methodological procedures.

The archaeological skeletal series had as an intrinsic characteristic to be non random funerary samples from the original population. Many factors were present during their constitution and these factors could not be completely recovered by the archeologists. Being an intrinsic characteristic of the archaeological funerary sample, this non random feature could not be efficiently avoided and as a direct result, the archaeological skeletal sample is very distinctive from the regular population samples used in epidemiological research. The archaeological skeletal sample does not have all the required characteristics needed to make prevalence comparisons following the epidemiological and statistical parameters (Waldron 1994).

Usually, there is a large variability in the sex and age composition as well in the sample size (number of all skeletons which could be analyzed) among different archeological skeleton series. 
The most common situation is that the sample size and the sex and age composition for the whole recovered sample was not the same that the sample size and sex and age composition in the sample effectively used in the paleopathological research. The sample sizes and sex and age composition usually change for each paleopathological aspect analyzed. These changes are, mainly, due to the differential preservation affecting the skeleton and could impose restrictions to make valid comparisons between samples.

As a supplementary issue, the diagnostic of caries in skeletons is different from the clinical diagnostic performed in modern patients. It is not possible to make a reliable differential diagnostic on hypocalcification spots in skeletal remains; so many initial caries could not be diagnosed. Taphonomic changes are other possible confusing factors that could produce caries-like lesions.

The characteristics of the archeological skeletal remains, combined with the characteristics of the paleopathological diagnosis, makes it very difficult to assure the comparability of the results found in different skeletal series in different research and/or for different research workers.

Only prevalence values calculated in the same way, over lesions diagnosed using the same diagnostic criterion and performed for the samples with similar composition (size, sex, age) could be compared in a significant way.

It is evident through this review, that the complete and clear methodological criteria and material description in dental caries paleopathological research are not being recognized as a central issue for researchers.

The given methodological information in the majority of the analyzed papers is not sufficient to make clear central issues like:

How exactly the analyzed sample differs from the whole skeletal sample recovered from the archeological site? What is the composition of the analyzed sample for sex and age? What are the diagnostic criteria? Which are the distribution characteristics of the cavities according to affected teeth and affected individuals? What is the accuracy of the diagnosis (minimum lesion size considered, cleanness of the analized material, use of magnification instrument).

This review strongly points to the fact that the most frequent in the paleopathology literature, at least in the last five years, are papers that lack fundamental methodological information and comparisons made without any guarantee that the compared prevalence are equivalent comparable elements. The consequence is that none of the comparisons made using this data could be really meaningful to understand the dynamics of dental caries in the past.

The current concept of caries assumes that it is a multifactor infection disease with an etiological bacterial agent and involves many others elements, such as, diet, susceptibility, dental hygiene, etc. However in the papers reviewed here the diet is considered as the main factor implicated in the dental caries development. At the same time all analyzed papers used the diet to explain the caries prevalence they found, only a few tried to demonstrate the role of other factors in the cavities development. Always that other element without diet was considered as playing a cariogenic role it was view as having a minor importance.

Several lines of evidence were used to connect caries to diet and to explain the observed caries prevalence using diet characteristics. These included clinical trials and also comparisons of caries prevalence verified between contemporaneous Native Americans, African, and Australian Aborigines, all living under traditional economies systems In addition study of dental caries prevalence in ancient human groups (pre-historic or historic) with well know economic systems were used.

The results found in this review suggest a need for more published analises, with particular attention to details of methods and methodological descriptions This will improve the present knowledge in the relationship between diet and dental caries in ancient human groups.

The results found in this review point to the fact that to investigate how other factors than diet affect the cariogenic process is not a concern in the majority of stidues.

The standardization of methods to study dental caries in skeletal samples, the explicit description of analytical procedures used and the explicit and accurate characterization of the samples (or of the reasons for the non publication of this data) need be a concern in the future research.

It is fundamental to improve research that caries are studied as a multifactor infection disease and that the role played for others factors than diet in the development of this disease are investigated.

\section{REFERENCES}

Antunes-Ferreira N, Cardoso O, Cunha E 2000. Paleobiologia de um grupo populacional medieval de São Pedro de Canaferrim. In VO Jorge, Contributos das Ciências e das Tecnologias para a Arqueologia da Península Ibérica, Actas do $3^{\circ}$ Congresso de Arqueologia Peninsular, Porto, p. 408418.

Buikstra JE, Cook DC 1994. Paleopatologia. In AJG Araújo, LF Ferreira, Paleopatologia e Paleoparasitologia: Estudos Multidisciplinares, Panorama ENSP/Fiocruz, Rio de Janeiro, p. 41-85.

Carnim G, Isidoro J, Reis MP 2000. Uma necrópole alto-medieval em Serpa: Primeiros resultados paleobiológicos. In VO Jorge, Contributos das Ciências e das Tecnologias para a Arqueologia da Península Ibérica, Actas do $3^{\circ}$ Congresso de Arqueologia Peninsular, Porto, p. 425-429.

Carvalho C, Cunha E, Silva AM 2000. Contribuição para o conhecimento da comunidade religiosa das Clarissas do Convento de Aracoelli (secs. XVII-XIX). In VO Jorge, Contributos das Ciencias e das Tecnologias para a Arqueologia da Península Ibérica, Actas do $3^{\circ}$ Congresso de Arqueologia Peninsular, Porto, p. 441-448.

Cohen MN, Armelagos GJ 1984. Paleopathology at the Origins of Agriculture, Academic Press, New York, 615 pp.

Cunha E, Cardoso F 2001. The osteological series from Cabeço da Amoreira (Muge, Portugal). Bull Mem Soc Anthropol Paris 13: 323--333.

Cunha E, Umbelino C 2001 Mesolithic people from Portugal: 
an approach to Sado osteological series. Anthropologie 39: $125-132$.

Cunha E, Umbelino C 2003. Paleobiology of the MesolithicNeolithic transition in Portugal: The state of knowledge. In J Bruzek, B Vandermeersch, MD Garralda (eds), Changements Biologiques et Culturels en Europe de la Fin du Paléolithique Moyen au Néolithique, Université Bordeaux, Bordeaux, p. 159-168.

Cunha E, Cardoso F, Umbelino C 2003. Inferences about Mesolithic life style on the basis of anthropological data. The case of the Portuguese shell middens. In L Larson, H Kindgren, K Knutsson, D Loeffler, A Akerlund (eds), Mesolithic on the Movie: Papers Presented at the Sixth International Conference on the Mesolithic in Europe, Oxbow Books, Oxford, p. 84-188.

Davidson JM, Rose JC, Gutmann MP, Haines MR, Condon K, Condon C 2000. The quality of African-american life in the old southwestern near the turn of the tweentieth century. In RH Steckel, JC Rose (eds), The Backbone of History: Health and Nutrition in the Western Hemisphere, Cambridge University Press, Cambridge, p. 226-282.

Domett K, Tayles N, Nelsen K 2000 Agriculture and dental caries? The case of rice in prehistoric Southeast Asia. Am J Phys Anthropol 30 (Suppl.): 141.

Higgins RL, Haines MR, Walsh L, Sirianne JI 2002. The poor in the mid-nineteenth-century northeastern United States: Evidence from the Monroe County Almshouse, Rochester, New York. In RH Steckel, JC Rose (eds), The Backbone of History: Health and Nutrition in the Western Hemisphere, Cambridge University Press, Cambridge, p. 162-184.

Indriarti E, Buikstra J 2001 Coca chewing in prehistoric coastal Peru: dental evidence. Am J Phys Anthropol 114: 242-257.

Johansson SR, Owsley D 2002. Welfare history on the Great Plains: mortality and skeletal health, 1650 to 1900 . In RH Steckel, JC Rose (eds), The Backbone of History: Health and Nutrition in the Western Hemisphere, Cambridge University Press, Cambridge, p. 524-560.

Larsen CS, Crosby AW, Griffin MC, Hutchinson DL, Ruff CB, Russel. KF, Schoeninger MJ, Sering LE, Simpson SW, Takács JL, Teaford MF 2002. A biohistory of health and behavior in Georgia Bight: the agricultural transition and the impact of European contact. In RH Steckel, JC Rose (eds), The Backbone of History: Health and Nutrition in the Western Hemisphere, Cambridge University Press, Cambridge, p. 406-439.

Lopes C, Cardoso FA, Cunha E 2000. Patologia Oral nas Clarissas de Coimbra entre os séculos XIV e XVII. In VO Jorge, Contributos das Ciências e das Tecnologias para a Arqueologia da Península Ibérica, Actas do $3^{\circ}$ Congresso de Arqueologia Peninsular, Porto, p. 431-440.

Morfin L.M, McCaa R, Storey R, Angel A 2002. Health and nutrition in pre-Hispanic Mesoamerica. In RH Steckel, JC Rose (eds), The Backbone of History: Health and Nutrition in the Western Hemisphere, Cambridge University Press, Cambridge, p. 307-342.

Nelson G, Lukacs J, Yule P 1999. Dates, caries and early tooth loss during the Iron Age of Oman. Am J Phys Anthropol 108: 333-344.

Neves WA, Wesolowski V 2002. Economy, nutrition and disease in prehistoric coastal Brazil: a case study from the state of Santa Catarina. In RH Steckel, JC Rose (eds), The Backbone of History: Health and Nutrition in the Western Hemisphere, Cambridge University Press, Cambridge, p. 376-405.

Pechenkina EA, Benfer RA, Zhijun W 2002. Diet and health changes at the end of the Chinese Neolithic: The Yangshao/ Longhan transition in Shaanxi Province. Am J Phys Anthropol 117: 15-36.

Rodrigues RL, Mauri JMG, Briones RC 2000 Estudio antropológico de cinco sepulturas prehistóricas de castilleja de Gusmán (Sevilla). In VO Jorge, Contributos das Ciências e das Tecnologias para a Arqueologia da Península Ibérica, Actas do $3^{\circ}$ Congresso de Arqueologia Peninsular, Porto, p. 343-362.

Santos AL, Matos R 2000. Quarto com vista sobre o passado: análise paleoantropológica preliminar na pousada da Nossa Sra. da Assunção em Arraiolos (Portugal). In VO Jorge, Contributos das Ciências e das Tecnologias para a Arqueologia da Península Ibérica, Actas do $3^{\circ}$ Congresso de Arqueologia Peninsular, Porto, p. 449-458.

Sciulli PW, Oberly J 2002. Native americans in eastern North America: The southern Great Lakes and upper Ohio Valley. In RH Steckel, JC Rose (eds), The Backbone of History: Health and Nutrition in the Western Hemisphere, Cambridge University Press, Cambridge, p. 440-480.

Silva AM 2000. Dental anthropology of calcholithic portuguese population from Cova da Moura (Torres Vedras, Portugal). Permanent lower teeth. In TA Varela, Investigationes en Biodiversidad Humana, Universidade de Santiago de Campostela, Santiago de Compostela, p. 367-374.

Sledzik PS, Sandberg LG 2002. The effects of nineteenth-century military service on health. In RH Steckel, JC Rose (eds), The Backbone of History: Health and Nutrition in the Western Hemisphere, Cambridge University Press, Cambridge, p. 185--207.

Stodder ALW, Martin DL, Goodman AH, Reff DT 2000. Cultural longevity and biological stress in the American southwest. In RH Steckel, JC Rose (eds), The Backbone of History: Health and Nutrition in the Western Hemisphere, Cambridge University Press, Cambridge, p. 481-505.

Storey R, Morfin LM, Smith V 2000. Social disruption and the Maya civilization of Mesoamerica: a study of health and economy of the last thousand years. In RH Steckel, JC Rose (eds), The Backbone of History: Health and Nutrition in the Western Hemisphere, Cambridge University Press, Cambridge, p. 283-306.

Turner II CG 1979. Dental anthropological indications of agriculture among the Jomon people of central Japan. Am J Phys Anthropol 51: 619-636.

Ubelaker DH 2000. Human Remains from La Florida, Quito, Ecuador. Smithsonian Contributions to Anthropology, 43, Smithsonian Institution Press, Washington,

Ubelaker DH, Newson LA 2002. Patterns of health and nutrition in prehistoric and historic Ecuador. In RH Steckel, JC Rose (eds), The Backbone of History: Health and Nutrition in the Western Hemisphere, Cambridge University Press, Cambridge, p. 343-375.

Ubelaker DH, Ripley CE 1999. The Ossuary of San Francisco Church, Quito, Ecuador: Human Skeletal Biology, Smith- 
sonian Contributions to Anthropology, 42. Smithsonian Institution Press, Washington.

Waldron T 1994. Counting the Dead. The Epidemiology of Skeletal Populations, Willey \& Sons, New York, 124 pp.

Walker PL, Thornton R 2002. Health, nutrition and demographic change in native California. In RH Steckel, JC Rose (eds), The Backbone of History: Health and Nutrition in the Western Hemisphere, Cambridge University Press, Cambridge, p. 506-523.
Waugh DB 1930. A study of the nutrition and teeth of the Eskimo of North Bering sea and artic Alaska. J Dent Res 10: 387-393.

Waugh DB 1931. A study of the nutrition and teeth of the Eskimo of North Bering sea and artic Alaska. J Dent Res 11: 453457.

Waugh DB, Waugh LM 1940. Effects of natural and refined sugars on oral lactobacilli and caries among primitive Eskimos. Am J Dis Child 59: 483-489. 
